\title{
Americanization of Non-American Storiesin Disney Films
}

\author{
Beta Setiawati \\ Language Center, Muhammadiyah University of Surakarta \\ Jl. A. Yani Tromol Pos 1 Surakarta
}

\begin{abstract}
The study is intended to know the Disney's animation films characteristics which are adapted from non American stories that contain Americanization in order to be American popular culture products. This qualitative and library research is carried out within the field of American Studies. Disney's animated films which are regarded as artifacts in order to identify American society and culture is used as her primary data. She then compares those Disney films with the original stories to discover the changes in making those stories become American popular products. She furthermore uses the sources such as books, magazines, journals, articles, and also internet data for her secondary data. The result of this study shows that most of folk narratives which were used in Disney films were adapted from other countries' stories. However, Disney intentionally adapts foreign countries' stories in its animated films by using Disney formula to blow up the sale of its products. Since Disney is one of the most powerful media conglomerates in the world, it works endlessly to set out world entertainment. Disney formula in its animated films which has dominated those adapted films are only intended to obtain as much profit as possible without paying attention to the values in children entertainment.
\end{abstract}

Keywords: Americanization, Non American Stories, Animation, Popular culture, Formula

\begin{abstract}
Abstrak
Penelitian ini bertujuan untuk mengetahui karakteristik film animasi Disney yang diadaptasi dari cerita non Amerika yang mengandung unsure Amerikanisasi agar menjadi produk budaya Amerika yang populer. Penelitian kualitatif dan studi pustaka ini dilakukan dalam lingkup Studi Amerika . Film animasi Disney yang dianggap sebagai artefak untuk mengidentifikasi masyarakat dan budaya Amerika digunakan sebagai data primer. Dia
\end{abstract}

REGISTER, VOL. 1, N0. 1, 2008 
kemudian membandingkan film-film Disney dengan cerita aslinya untuk menemukan gubahan dalam pembuatan cerita-cerita agar menjadi produk populer Amerika . Dia selanjutnya menggunakan sumber seperti buku, majalah , jurnal, artikel, serta data internet sebagai data sekunder. Hasil penelitian menunjukkan bahwa sebagian besar cerita rakyat yang digunakan dalam film-film Disney diadaptasi dari cerita negara lain . Namun, Disney sengaja mengadaptasi cerita luar negeri dalam film animasi dengan menggunakan formula Disney untuk meledakkan penjualan produkproduknya . Karena Disney adalah salah satu konglomerat media yang paling kuat di dunia, karya-karyanya berhasil tanpa henti untuk meramaikan dunia hiburan. Formula Disney dalam bentuk film animasi yang telah mendominasi film-film yang diadaptasi hanya dimaksudkan untuk memperoleh keuntungan sebanyak mungkin tanpa memperhatikan nilai-nilai pada hiburan anak.

Kata Kunci: Amerikanisasi, Cerita Non Amerika, Animasi, BudayaPopuler, Formula

\section{Introduction}

Walt Disney Corporation is one of the American media conglomerates which have monopoly control of global news and entertainment. It has not only won the hardware and the wires but also, increasingly, the content. Over the course of the more than 80 years in operating the company, Walt Disney Company has practically become synonymous with the medium of hand-drawn animation. Wasko stated that "it has been regarded as the best American company which provides predictable and reliable family entertainment through its animated feature films" (2001: 112). This corporate control grants Disney the power to create cultural icons and allows them to shape and limit the audiences' perception of reality which works to create a normative vision of the world. Walt Disney, the man who is behind that huge company is a legend and a folk hero of the 20th century. His worldwide popularity was based upon the ideals which his

REGISTER, VOL. 1, N0. 1, 2008 
name represents: imagination, optimism, creation, and self-made success in the American tradition. It brought the people closer to the future, while telling them of the past. Walt Disney with his enterprises in film, video, theme parks, cable, and network television, cruise ships, toys, clothing, and other consumer products, leads in the construction and promotion of U.S. popular culture. "Even, Disney now serves as America's moral educator" (Real,1977: 52). "Dominating market power in entertainment mitigated by avuncular representation adheres to Disney in large part due to its primary production art form, the animated feature" (Ward, 1993: 171).

For many years the Walt Disney Company has given the United States and many other countries with unforgettable fairy-tales, love stories, and magical animated adventures. Since its inception, Disney has given them adaptations of many famous folk tales such as Cinderella, Bambi, Lion King, Mulan, Aladdin, and so on. It has then evolved into a company that strives to adapt aspects of many other cultures into its masterpieces, and it is most likely done with good intentions. However, in its efforts to expose viewers to other cultures, the storytelling can leave people that are culturally aware or sensitive with a sense that the films are merely bastardization from the original tales and culture. It also promotes a sense of west over east or white supremacy. It is in line with the definition of Americanization as the term used for describing the influence of the United States of America on the culture of other countries. It also means that "it is a kind of process to substitute other culture with American culture" (Chang and Ha-Joon,2003: 34). Though, the word "Disney" is synonymous with innocence to most parents. In fact, there are certain social ideologies indirectly embedded within even the most classic, beloved, and timeless Disney's animated motion pictures.

REGISTER, VOL. 1, N0. 1, 2008 
The study discusses Disney's animated film characteristics. From that point, it can explore the ways and reason of Disney in wrapping non American stories to be its products. Here, the writer only investigates the construction, setting, and content of Aladdin (1992), Mulan (1998), Hunchback of Notre Dame (1996), and Beauty and the Beast (1991). Those non American stories will be blended in the analysis with some other stories such as Lion King, Cinderella, Little Mermaid, etc. Those four films have non American story background such as Aladdin (Arab), Mulan (China), Hunchback of Notre Dame (French), and Beauty and the Beast (French). Those stories come from other countries which must have different cultural background from America.

\section{Discussion}

\section{Racism in Disney films}

In the hand of Walt Disney, many fairy tales, legends, or ballads from other countries were remade into U.S versions for American viewers. They adapt the story to extend the market and adapt to American culture. Most of these "Americanized" versions were filmed in American places, and with English-speaking actors. In some cases, an original story from a foreign country is Americanized by recasting its leading characters as Americans. Through years of growth and development, the Disney Company has been able to place their products and images in the lives of almost all children in America and other countries in the world.

Even though each culture has their own unique traditions and history, Walt Disney does not always portray them accurately. There are many ideologies about the characteristics of various races which show that the one is superior to the rest. These cultural notions are often translated to a variety

REGISTER, VOL. 1, N0. 1, 2008 
of America's visual culture, including animation and the Disney Company (Bell et.al, 1995: 171). 'If one was to list all 44 of Disney's classic hand drawn animated features, they would notice that all but three of the approximately 22 movies telling the story of humans feature those who are not white, while the rest of the animal based tales are predominantly voiced by Caucasians" (Maio, 1999: 4). Every other race is clearly underrepresented. When they are included in the film, they appear as stereotypical representation of other nations who are often described as inferior, ridiculous, wicked, and impolite. Beside that, Disney has the great ability to shape and frame some values from other countries' stories to be the products of American popular culture.

The movie that depicts the Arabic culture is 1992's mega hit Aladdin. The Aladdin film is regarded as racist by Arab American groups in the United States (Maio, 1999: 4). Before the real movie even begins the barbaric attitude is established in the very controversial song Arabian Night. Parts of the song's lyrics announce:

"Where they cut off your ear If they don't like your face, It's barbaric, but hey, it's home".

The lyrics so offended particular viewers that the American-Arab AntiDiscrimination Committee insisted that Disney change the lyrics. Kanfer stated that after some consideration, two of the three lines were changed to:

"Where it's flat and immense,

And the heat is intense,

It's barbaric, but hey, it's home". (1997: 177)

Even though the most offensive parts of the original lyrics were replaced, the fact still remains that Disney is trying to stress the barbaric culture of the Arab world. Because Disney did not remove the final line from

REGISTER, VOL. 1, N0. 1, 2008 
the song even after the company was aware of dissatisfaction from its Arab audience, the Aladdin film is racist.

In addition, it seems that Disney wants to expose that only in one country, Saudi Arabia, there was a punishment by removing one's hand and beheading one's head. It means that the country is still barbaric place. During the movie, the merchant tries to chop off Princess Jasmine's hand when she takes an apple to give to a starving child. The merchant does not know that she will pay for it. It is also contradictive to the Islamic faith and the vow to feed the poor or hungry people. In other side, when Aladdin helps Jasmine to run away from sultan's palace, the palace's guards cry out to behead him. The readers of Arabian Night must be confused with the film since they can not find those parts in their reading.

\section{Discrimination in Disney films}

Disney's animators can also project American made stereotypes into their animation. We can take an example, all evil characters in Aladdin such as Jafar and the sultan's guards have beards and large, bulbous noses, sinister eyes, and heavy Arabic accents. They usually use sword constantly (Giroux, 1999: 32). Scheinin added in Ostmanthat Aladdin was modeled on the American actor, Tom Cruise. The heroes such as Aladdin and Jasmine, however, are light skinned, speak with American accents. Aladdin does not have beard, turban, or an Arabic accent because Aladdin is voiced by Scott Weinger (1996: 24). Even people call him 'Al', an American name. The original Princess Badroulbadour became Jasmine. In the film, she is not a traditional Arab princess who always wears veil anymore but a beautiful belly dancer. A belly dancer is regarded as traditionally lower status to the Arab in the view of people in the world (http://en.wikipedia.org/wiki/Stereotypes_of_Arabs_and_Muslims). Jasmine

REGISTER, VOL. 1, N0. 1, 2008 
in Disney's Aladdin had a sense of sexuality rather than royalty. Jasmine's innocent sexuality is common for the female characters of Disney movies. Even though Disney adapts and wants to tell the story of a non white culture, Arabian culture, all of his main characters are practically American. This ethnic and nationalistic stereotyping is not a new phenomenon in Disney cartoons or in animation generally. As Schweizer pointed out that "this submerged nationalistic propaganda can be seen as early as Pinocchio in 1940 in which the protagonist, Pinocchio and the good fairy both have American accents, but villainous character have either Italian or English accents “(1998:67).

Less blatant discrimination can be found in Disney's The Lion King. Even though "the picture uses an African tribalism culture, as well as makes its setting within the continent of Africa, there is not a single character with African characteristics. Instead of using African humans in the film, Disney opted to replace them with animals" (Kilpatrick and Jacquelyn, 1995). This is relevant to American society because the society has not yet fully embraced African-Americans as being completely accepted. Although modern America is more than willing to acknowledge the culture and habits of African Americans, like we can see in the movie tribalism, it is not ready to fully accept African color as the norm. It is shown to the using animals instead of African humans in Disney's Lion King. African Americans will always be different in the eyes of the white majority of America, if only by skin color. "Disney chose to intentionally overlook the inclusion of Africans so that there would not be the chance of offending an immense number of African Americans with unintentional production errors" (Kilpatrick and Jacquelyn, 1995: 5).

We can also assume that The Lion King is also home to many American overtones. Disney depicted the villains, hyenas, as unintelligent

REGISTER, VOL. 1, N0. 1, 2008 
creatures living a barren, lifeless area, the rough equivalent of the slums and ghettos of America. The hyenas are the equivalent of American minorities who live in these slums, and are portrayed negatively. The lions that live in the areas of rich vegetation and animal-life, on the other hand, are portrayed as the heroes, the positive side of the vast society used in the story. Additionally, African-Americans voice actors were intentionally hired to voice the lower and unintelligent characters (Kanfer, 1997: 179). The American tendency to correlate minority figures living in the less well-to-do areas of the country with societal negativity can be interpreted through this movie. "The crows in 1941's Dumbo have distinctively black voices while one is even named Jim. It was clearly referencing the historic Jim Crow laws which promoted segregation against African American and now it becomes a taboo label for black people" (Kanfer, 1997: 178). He also added that Disney does not only portray them in feathers but also as good hearted and chuckleheaded simpletons whose skills are confined to singing and dancing. Even though none of the characters in the examples above are visibly black, Disney attaches and implies a meaning by using the voice with the image. Tavin explains how animals and non-human representations in Disney films are not immune to this racial stereotyping. The characters often use language in the form of racially coded accents and inflection (Tavin et.al., 2003: 5657).

Audience can also observe in another Disney movie that takes place in Africa, 1999 Tarzan which eliminates the presence of blacks in Africa altogether. It also promotes white supremacy to any who view that film. There is the same case in the relationship between Pocahontas and John Smith in Disney's Pocahontas. Even though the white people in this movie are the enemy, there is still a suggestion of white supremacy because Pocahontas essentially falls in love with the first white man she sees

REGISTER, VOL. 1, N0. 1, 2008 
(Edgerton and Jackson, 1996: 92). In real life, Pocahontas was a very young girl of 12 years old and in fact, she never had any romantic relationship with John Smith(http://en.wikipedia.org/wiki/Pocahontas_History) who is described as a blond, smoothly muscular, and athletically animated in Disney's film. While Chief Powhatan appears more sedate in bold, symmetrical strokes, with slower and more dignified screen movement and dialogue. John Smith can fulfills his heroic ideal in vision and plot because in the end of the film, the good colonialist intervenes to save Powhatan and order to arrest of Ratcliffe, the villain. The facts above show us that Disney's art is also reflective of America's glorification of white culture. Even if it was done unconsciously, Disney's animations help to create a society in which its members conform to the life of white people. In America, being white is seen as being powerful and in control. As a result, characters with stereotypically non white characteristics may be regarded as a different race, such as the evil villains or troublemakers.

In Disney's Hunchback of Notre Dame, Judge Claude Frollo, the French Minister of Justice is narrated as a harsh character. He catches and kills one of the gypsy women who want to enter Notre Dame. The killed woman brings the bundle which contains a baby. Frollo then realizes that her bundle is a deformed baby, which he attempts to drown because he believes that he is an unholy demon. He is stopped by the Archdeacon, who tells him to care for the child to save his own soul from going to Hell for killing an innocent woman. He reluctantly agrees, naming the baby Quasimodo, which means 'half-formed'. The movie formulates the cruelty of Judge Frollo to describe the condition of French's justice. In fact, Hugo's novel did not tell the same. In Hugo's novel, we are told about Quasimodo's background. How he was found as a hideous and abandoned baby and taken in by Claude Frollo, the archdeacon of Notre Dame. His love for Frollo because he has

REGISTER, VOL. 1, N0. 1, 2008 
grown him up was described clearly in the novel. Frollo is shown to be a formidably intellectual man, forced early on to become a parental figure because he and his younger brother, are left by their parents in young age or they

are orphaned(http://en.wikipedia.org/wiki/The_Hunchback_of_Notre_Dame).

In Hugo's novel, Quasimodo was not arrested andlocked in the belltower to protect him from the cruel and wicked world below by Frollo but free. In the film, Frollo insists that Quasimodo should not be among people as cruel as his mother, who abandoned him, and that he must obey Frollo's requests in order to thank Frollo for taking him in and raising him as his son. Quasimodo is watched over by his three guardian angels in the form of stone gargyoles: Victor, Hugo and Laverne. It proofs that Disney tried to describe Quasimodo's desire to be free or to get freedom which is absent in Hugo's novel. It is also unfair to describe the cruelty of Frollo as a French Minister of Justice since it can give certain stereotypes about French justice to the audience. It also shows that Esmeralda's execution is done by burning her at the stake in front of the cathedral. In fact, Notre Dame cathedral is a Gothiccathedral on the eastern half of the Île de la Cité in Paris, France. It is still used as a Roman Catholic cathedral and is the seat of the Archbishop of Paris. (http://en.wikipedia.org/wiki/Notre_Dame_de_Paris). Whereas in the novel, she is only hanged. As with many of its animated films released during 90s, then Disney's Hunchback of Notre Dame can be read as discouragement of French national culture(http://www.case.edu/alfil/sce/Texts_2001/Needham).

\section{Feminism in Disney films}

A more American concept in Disney's films is feminism. Referring to the issue of American feminism, Disney tried to bring the concept of 
American feminism to his film Beauty and the Beast. Empowered by her intelligence and book smarts, the young heroine Belle in Beauty and the Beast, is portrayed as an independent woman stuck in a provincial village in eighteenth century France. The people see her as odd because she always has her nose in a book. She is pursued by Gaston, the ultimate vain, macho male typical of Hollywood films of the 1980s but Belle rejects him. In the end she gives her love to the Beast who holds her captive in the hopes she will fall in love with him and break her fear of him as a young horrific man. When her father is imprisoned by a beast, Belle goes to save him. She then decides to make a deal actively, so her father goes back home and Belle takes his father's place bravely in the Beast's castle (http://en.wikipedia.org/wiki/Beauty_and_the_Beast-Film). Belle does not only fall in love with the Beast, but she also "civilizes" him by instructing him on how to eat properly, control his temper, and dance. Belle becomesa model of brave, smart, and active woman who is able to change every single bad thing to be the good one. She has power to transform the Beast to be the one who is sensitive, caring, and loving. In the end, Belle simply becomes another woman whose life is valued for solving a man's problems.

Disney has changed the original story in the Mme Jeanne-Marie Leprince de Beaumont's Beauty and the Beast. In Beaumont's story, Beauty is an obedient girl. When her father lost in a forest and caught in a storm, he found shelter in the Beast's palace. As he leaves, he plucks a rose to bring back to Beauty, offending his unseen host, who denouncing him as a thief, tells him he must now die. The father begs to be allowed to see his daughters again. The Beast says that if one of the man's daughters will return to suffer in his place, he may live. Beauty journeys to the Beast's castle convinced she will be killed, but instead she is made mistress of the enchanted palace, and the Beast asks her to be his wife. She says she can be his friend, and will stay

REGISTER, VOL. 1, N0. 1, 2008 
with him forever. She entrusts her life totally without any effort to make her condition better. She does not try to civilize the Beast at all. Disney makes the magic on passive Belle in this film so the audiences always miss its next romantic films.

The same case is occurred in Aladdin film. In the story of Arabian Night, Princess Badroulbadour lives under her father's rules. She is a veiled girl who is always in the palace all along day without any complaints. The Sultan has arranged her marriage. After being married by the rich Aladdin, she lives in her own palace. She never knows her husband's business at all. Even, she asks her slave to change the old lamp of Aladdin, which is in fact, the magic lamp, with the newest lamp. It shows that the princess still lives in the place which applies traditional gender role. In contrast with Princess Jasmine in Disney's Aladdin, Jasmine is another free-spirited, smart, active, and rebellious girl who wants everyone to know that she can do everything the boys can. Jasmine, the teenage daughter of the Sultan, who must be married before her upcoming birthday, has great power to reject every prince she meets because she wants to be married for true love. She runs away from her palace to have free life skilfully as if she is used to be street girl. She also adapt the ordinary people's life fast. She is able to arrange her own life without influence of people around her. Moreover, she has great power to influence her father's law which asks her to marry a prince so that Jasmine can marry anyone she chooses, Alladin.

Disney's concept of feminism is also visible in Mulan which was used by Disney as a platform to jump into the Chinese market and released in the midst of intensifying anti-Chinese sentiment in the United States (Nguyen, 2001: 8).The animators have drawn their visual inspiration from Chinese and Japanese sources in Mulan. The characters' simple lines and the clean look of the backgrounds remind people of classic Asian painting. Plus, the

REGISTER, VOL. 1, N0. 1, 2008 
filmmakers haven't "Westernized" the characters' features (Budd, 1999 90). While there were several cultural aspects incorporated in the making of Mulan such as the importance of honor and shame in society, Mulan is simply a mirror for American feminist ideas, which reflects the modern perception of the woman as a person that is just as capable, if not better, at doing anything males can. The young Chinese girl rendered an entire army of males completely useless.

In the legend, it was told that Hua Mulan distinguished herself in battle and was promoted up the ranks. Eventually she became a general known for her brilliant military strategies. All through her 12 year military career, no one ever found out that Hua Mulan was a woman. According to history, when the war was over, the emperor asked General Hua what reward "he" would like. General Hua said he had no use for high official positions and only asked for a speedy horse to take him home to his parents. General Hua went home ,by that time she was about thirty years old and returned to the weaving loom which she left before the war (http://en.wikipedia.org/wiki/Hua_Mulan). The audience can not find the part that Mulan's friends knew her pretending as a man as we see in the film. Disney made the trick of Mulan that is found as a woman in the middle of the story to expose American feminist idea which now becomes the idea of modern women in the world.

Gender is an important topic in today's society. Most people feel pressure to conform to certain gender stereotypes without really understanding what they are and even without being aware of their influence on our perceptions. Gender roles are the qualities and characteristics that are considered essentially feminine or masculine. The traditional gender role rules that a woman's place is in the home while a man's place is to provide for the family. "The media often uses gender to its advantage and Disney

REGISTER, VOL. 1, N0. 1, 2008 
productions are not different" (Bell, 1995: 80). Many people are also concerned with the portrayal of women and the questionable behavior in Disney films. In Disney's stories, mothers are missing and men rule the society. Bambi's mother is killed. Snow White's mother tries to kill her and is ultimately killed. Belle, Cinderella, Ariel, Pocahontas, Quasimodo, Aladdin are all motherless. Filling the motherless in these films are over protective fathers such as Triton in Little Mermaid, eccentric father Maurice in Beauty and the Beast. Men exist to save and protect girls and rule kingdoms. Typically women are shown in a position of princess, queen, or homemaker, for example, Ariel in the Little Mermaid, Jasmine in Aladdin, Belle in Beauty and the Beast, and so on. Cinderella is a maid and then a princess. It seems as if women are seen as a commodity in a patriarchal society. It also seems that they are illustrated as being subservient to the male characters who typically display powerful behaviors, such as Gaston in Beauty and the Beast, Phoebus in Hunchback OfNotre Dame, Aladdin, etc. They are portrayed using forceful behavior in order to get what they want.

\section{Male Dominance in Disney films}

As early as Disney's first animated classic, there has always been an emphasis on male dominance for nearly every film. Prince Charming kisses Snow White and brings her back from the dead. Then he rides happily ever after with her to his castle in the clouds. Whereas, in the original Snow White that is well known in Europe, Snow White is waken up from the coffin because the prince and his men carried the coffin away. The coffin jerked and the piece of poison apple flew out of Snow White's mouth, awakening her. The prince then declared his love and soon a wedding was planned. Disney made as if the prince can make Snow White alived. This also appeared in Disney's Cinderella. Cinderella's Prince is smart enough to find her and 
rescue her from the clutches of the Evil Stepmother. It is similar when Belle takes over the castle as if she is a house manager rather than as equal ruling partner because the film has led us to believe that this beauty does a great job of keeping homes. Jasmine as a Princess is ultimately subservient, to her father and to Aladdin. Pocahontas may save her man, but she is never in charge of anything. She is not a ruler. Mulan may be the best warrior in her country because she can save her country for the ruling males but she ultimately accepts her woman's role by going back home away from politics and power.

Going even further, many audiences do not see Cinderella's personality or actions in a negative light. She is a description of an ideal woman that is expected to be in Disney and American culture in general at the time. For the audiences of the movie, Cinderella has many admirable qualities, taking a more calm and discreet approach in fulfilling her wishes, and chooses to be kind even to those who mistreat her. The princesses of Cinderella and Snow White are the result of years of adversity at the hands of Walt Disney. They both seek their Prince charming to come and sweep them from their feet and take them from the harsh reality of life. Oddly enough, the princes in these two stories are merely conventional males, instilling the idea that females must remain a passive entity until the time when a man will actively pursue her. The construction of gender identity for girls and women also represents in both The LittleMermaid and The Lion King, the female characters are constructed within narrowly defined gender roles. All of the female characters in these films are ultimately subordinate to males, and define their sense of power and desire almost exclusively in terms of dominant male narratives, for instance, Ariel, the woman-mermaid in The Little Mermaid, at first glance appears to be engaged in a struggle against parental control. She is motivated by the desire to explore the human world

REGISTER, VOL. 1, N0. 1, 2008 
and willing to take a risk in defining the subject and object of her desires. But in the end, the struggle to gain independence from her father, Triton, and the sense of desperate striving that motivates her dissolves when Ariel makes a Mephistophelian pact with the sea witch, Ursula. In this trade, Ariel gives away her voice to gain a pair of legs so that she can pursue the handsome Prince Eric. While children might be delighted by Ariel's teenage rebelliousness, they are strongly positioned to believe in the end that desire, choice, and empowerment are closely linked to catching and loving handsome men.

We can as well implicitly see the traditional gender role in 1998's Mulan. While this film is not seemingly stereotypical on the outside with a brave and heroic female leader, it does include several negative American ideologies about China. The movie opens with a matchmaking scene. It implies that women can not think for themselves and are only useful in the home where they follow their husband's orders. Lyrics in the song "Honor to Us All recites: “Men wants girls with good taste, calm, obedient, who work fast pace, with good breeding and a tiny waist" (Christensen, 2004: 6). She adds that in fact, the arranged marriages that are portrayed here never took place in China. Here the animators are projecting mythical ideas and notions that Americans have about China into the movie and claiming it as reality. In another side in the movie, when Mulan attempts to vocally stop the army from enlisting her injured father, the emperor's assistant replies,"Silence! You will do well to teach your daughter to hold her tongue in a man's presence"(Christensen, 2004:7). While these examples also support ways in which Disney presents gender stereotypes, it also reflects on ill conceived ideas of the Asian culture.

In Disney's Hunchback of Notre Dame, Esmerelda's power comes from her sexuality. She is able to resist arrest because Captain Phoebus, the

REGISTER, VOL. 1, N0. 1, 2008 
blond-haired, blue-eyed hero who has fallen in love with her. She is also a gypsy, and because gypsies are witches, she is able to magically disappear to evade capture by Frollo's cronies. While seeking sanctuary in Notre Dame, she becomes friends with Quasimodo and discovers her dream. She is not seeking adventure, but help from God for the outcasts of the world. Because she and the gypsies "live outside the normal order," we don't expect her fate to fall within this order. For instance, she will not be marrying a handsome prince. In the film's climax, she is burned at the stake for witchcraft. She doesn't die of course. She is saved by Quasimodo. In the end, she presumably lives happily-ever-after with Phoebus. The traditional gender role in this film is exposed to change the main message of Hugo's novel which emphasizes Esmeralda's effort and trial as the main color of the novel.

The idea of male dominance in Snow White (1937), Cinderella (1950), The Little Mermaid, and The Lion King, while is not strictly an American concept, it still remains an example of society at that time through the media. Traditionally in American culture, a higher value has been given to whatever is defined as male. Harvard Law School, for example, did not open its doors to female students until 1950 (Marylyn,1996: 66). People can also find in Claudia Goldin's statement in her book Understanding the Gender Gap: An Economic History of American Women that "as the gendered work that men and women performed within the household economy was transferred to mill and factory, jobs were gendered" (Goldin, 1999: 22-24). She also stated that little value and low pay was attached to tasks usually performed by women. For minority women, sex discrimination in employment compounded racial and ethnic discrimination, placing them to jobs at the very bottom of the economic scale. Occupational segregation and lower wages, as well as unrecognized, uncompensated labor for those doing housework, left most women economically dependent on men (1989: 24). It

REGISTER, VOL. 1, N0. 1, 2008 
is clearly proved that sex discrimination still run in America in the nineteenth century.

\section{Rebelliousness of teenagers in Disney films}

Disney has also repeatedly supported the idea that teenagers are rebellious and deviant people. It is similar with the stereotype that plagues the majority of modern American teens. Today, the term teenager has a negative connotation (Ostman, 1996: 83). Support for this concept can be found very openly in The Little Mermaid. When the protagonist of the story, Ariel, is scolded by her father, King Triton, for disobeying an order, she leaves in tears. Sebastian, Triton's trusted advisor, can make sense of the situation by sarcastically uttering "teenagers...". More evidence is found in Aladdin, where the teenage Princess Jasmine runs from her palace home to the marketplace. In a matter of minutes, her arm is nearly removed by a shopkeeper for stealing an apple. The character Jim Hawkins from Disney's Treasure Planet is another example. He is introduced in the movie as a criminal youth that has trouble with the law and communicating with his mother (http://en.wikipedia.org/wiki/Treasure _Planet_Film). While The Ballad of Mulan tells of Mulan's decision to join the draft. Her openness about her decision, and her parents' knowledge of, and acceptance of her course of action are in direct opposition to the Mulan story presented by Disney, in which Mulan runs off in secret to her parents' dismay. It is also one point stresses in teenager rebellion. We can also find this characteristic in Hunchback of NotreDame film. As the Festival begins, the two of guards who arrest Quasimodo head into town to join and patrol the crowd. At the same time, Quasimodo sneaks out of the tower in disguise and watches the Festival, where Clopin and the Gypsies are performing the dance. Although Frollo does not allow him to appear in the crowd. In Beauty and the Beast,

REGISTER, VOL. 1, N0. 1, 2008 
Belle sneaks into the forbidden West Wing, discovering slashed furniture, broken mirrors, a ripped-up portrait with strangely familiar blue eyes, and the enchanted rose although Beast has forbidden her to go there. The Beast catches her and she flees the castle, only to encounter a pack of wolves. At the last minute, the Beast fights off the wolves and a grateful Belle returns to the castle and the two start to become friends.

\section{The concept of true love in Disney films}

In Disney tales there is one true love waiting out there for the hero or heroine. Cinderella, Sleeping Beauty, Little Mermaid, Beauty and the Beast, Lady and the Tramp, Pocahontas and others all celebrate this. There are problems in the lives of each of these characters: Sleeping Beauty and Snow White are dead and a kiss makes them alive and married. Pocahontas, Belle, Ariel and Cinderella are looking for a better life, looking beyond their bored, looking for existence for happiness. Of course happiness is defined as life with a man, one special man. Love at first sight is inevitable and appropriate. Furthermore Prince Eric should kiss Ariel whether she wants to be kissed or not, because she is "the one" and he has a duty to follow his feelings. There is one ideal romantic mate for everyone in Disney's stories. One must find this person and marry him or her to have a complete life. In Disney films it is not enjoyable to be single because it means to be lonely and unfulfilled.

\section{The importance of performance and wealthy in Disney films}

We can also observe that beauty or good looking is everything in Disney films. Most heroic characters in Disney stories are young. In Disney's world there are seldom characters that fall in love who are not beautiful or handsome. Even animals like Bambi and Lady and the Tramp are the best looking in their worlds. Hercules has the body of Arnold Schwarzenegger

REGISTER, VOL. 1, N0. 1, 2008 
(Chesebrow and Bertleson, 1996: 143). Belle's Beast is really just a young with a curse problem. Prince Charming is so charming and gorgeous to look at. Cinderella makes a big deal about dressing and being beautiful before going to her prince. Mulan is described as the most beautiful girl of Chinese girls who join in matchmaking. Pocahontas looks like a Barbie doll. They look beautiful or handsome, dress attractive, and marry good looking person.

In addition, being rich and powerful are more appealing in most of Disney films. In Pocahontas when the British first arrive, the Governor sings about the better life filled with mountains of gold. "It's gold and it's mine, mine, mine. There'll be heaps of it, and I'll be on top of the heap" (http://en.wikipedia.org/wiki/Pocahontas_film). The guards of sultan's palace in Aladdin also sings "Who has the gold has the rule" when they look for Aladdin because he helps Jasmine to run away from the palace. But Aladdin can marry Jasmine in the end of the story because he has more than the gold, magic lamp that can grant all his wishes. The Beast has a great wealth so he can guarantee Belle's enjoyable life. Mulan is not only a girl but also from the ordinary family in China but she can save the Chinese troops from the villain so she can get immense attention from the leader of the army, the Khan, and people all over her country. In The Lion King Simba enjoys a relative life of leisure while waiting to ascend to his inherited destiny as monarch. Cinderella works hard at the beginning of the film as an indentured servant but the happy ending for her is that she will never have to work again. Cinderella as the main character strives for a better life and finally she gets the one who is rich.

\section{The significance of magic in Disney films}

Success while the Disney heroes journey on their quests is achieved with the help of wishing and magic. It is not strictly done by the heroes' own

REGISTER, VOL. 1, N0. 1, 2008 
abilities and devices. Esmeralda is told as a gypsy, and because gypsies are witches, she is able to magically disappear to evade capture by Frollo's cronies. Pinocchio has Jiminy Cricket, his conscience. Dumbo has Timothy Mouse, his teacher. Ariel the mermaid has Sebastian the crab and Flounder the fish to guide and teach her. Belle the Beauty has mentors in the guise of talking furniture to help her find her true love. They also have the magic mirror to see the certain events. The Khan troop's practice and effort is nothing if it is compared with Mulan who has Mushu, an unusually small dragon that has been sent by her ancestors to bring Mulan back home savely. Mulan has her second good luck charm, a cricket named Cri-Kee. So that she can work hard and she is soon even stronger than the rest although Mulan starts out physically weak in comparison to her fellow soldiers. Finally she becomes a respected part of her group, which is led by Captain Li Shang. In other side, Aladdin is able to reach his dream by the help of smart mouthed genie inside the Magic Lamp and Jafar has a smart-mouthed parrot. Cinderella couldn't be successful without the Fairy Godmother and Cinderella herself is a friend and protector to the mice and other animals which are always ready to help her. In Pocahontas, John Smith learns many things from Pocahontas who get wisdom from the spirits. The wish or magic motif is also present in more recent Disney's productions.

The audiences are allowed to laugh at the developmentally disabled in some of Disney films. In Beauty and the Beast, Gaston's friend and assistant, Le Fou is clearly not very intelligent. Gaston slaps Le Fou around and verbally abuses him. These episodes are played in Disney film for laughs. Gus-Gus is the overweight mouse in Cinderella. The audiences usually laugh at this object because he is slow of mind. He is also slow of foot because of his girth and we have more reason for audiences and children laughter. The other proof is when the time comes to crown the ugliest member of the crowd

REGISTER, VOL. 1, N0. 1, 2008 
as the King of Fools in Hunchback of Notre Dame, Quasimodo is chosen and then crowned as the King of Fools. The humorous behavior of the crowd leading him to believe he is being honored. Moments later, the crowd ties him down and throws food at him. Then in another story, Dumbo is cruelly ridiculed by the gossipy, wicked female elephants, but clearly we are meant to see this as wrong behavior for the audience. However later in the film the likable and funny crows also make fun of Dumbo. The circus clowns use and abuse the big-eared Dumbo in hurtful ways (Kuenz, at.al., 1995: 112-114). Most everyone in Dumbo's world except his mother and Timothy mouse pretty much treat Dumbo with contempt and with cruel laughter. It's only after Dumbo proves himself by flying and becoming economically profitable to the circus does the disfigured baby elephant get respect from his circus peers. Thus, being ugly and disfigured is laughable and reason for scorn. However, being disfigured is just fine as long as you bring money into the circus and spread the wealth around. Riches make the sarcastic laughter go away.

\section{Culture distortion in Disney films}

There are some kinds of historical distortions that are done by Disney Corporation in creating stories' adaptation to some serious literatures which have helped to define cultures. The Disney version of Victor Hugo's The Hunchback of Notre Dame outraged French critics and citizenry (Schickel, 1998: 120). Disney took a significant part of French literary history and added talking gargoyles, a kindler, gentler Hunchback character. The audiences can not find deaths or murders in this story. Disney tacked on a romantic happy ending for good measure. Hugo's original tale is hardly recognizable in this Disney's film. Another example of literary distortion involves the Greek story, Hercules. In Disney's film version, Hercules kills

REGISTER, VOL. 1, N0. 1, 2008 
the Minotaur which was Theseus in legend. Zeus, rather than being the womanizer of the Gods is a kind of an animated immortal "Father Knows Best" of the skies. In the film Hercules' mother is Hera when in fact Hercules' mother was Zeus' mistress Alcmene. In Disney’s version Hercules slays the Medusa when in the Greek myth it was actually Perseus (http://en.wikipedia.org/wiki/Hercules_Film). The second type of distortion which occurs in Disney tales is the blatant corruption of historical fact and real-life people. Pocahontas was an actual person who never had a romance with John Smith and in fact married one of the other members of Smith's crew and went back with him to Great Britain. There she died of a disease at an early age. Contrast this to the final scene of the Disney version of this story as Pocahontas says goodbye to her lover, John Smith, as the British crew sails back to England without her (Edgerton and Jackson, 1996: 93). The audiences also can not find the true history in Disney's Mulan. Mulan, the story which celebrates the Chinese heroine, distorts the history and facts of the events which took place. In the real life legend, Mu-Lan did not need a Dragon to help her win battles. Mulan is not offered a job as a confidant to the Emperor because of her heroism in the legend. It was something which Disney creators simply made up. Those stories are distorted for a modern audience who will not be educated about the history of other nations' cultures since the modern audience usually ignore them.

Disney has assured market demand and follows an industry trend of making more money from the sales of video tapes than from box office receipts (Van, 1990: 66). There are two questions which are tacitly stated in these video advertisements. The first is as parents how parents can deny their children own and buy re-watchable copy of the latest special animated video release, and the second is as parents how they dare deny their children the archetypal magic and myths of childhood.

REGISTER, VOL. 1, N0. 1, 2008 
Although many adults are also included as Disney's films consumers, most of those films' audiences are children. Statistics show that "74 percent of children say that they want to copy what they see in the movies" ( Schweizer, 1998: 68). Sooner than later, children accept what they see in these animation as the "truth", and do not question whether or not what they see on the screen matches that of the real world around them because their brains are constantly trying to make sense of the world around them. In addition, Schweizer believes that children instead focus on the most dramatic images they can see. They also begin constructing their own identities, as well as a feeling about who they are and what they look like in comparison to these images. The simplicity of the visual appearance of a cartoon character allows a person to project themselves onto the character and become so engrossed that they "become" the cartoon. This suggest that children's fascination with character in animation is not random influences their views on the cultures of the world (1998: 69). As the result, parents and teachers must be aware of this and be willing to converse with their children about what they are seeing in Disney films and all popular culture because the Disney Company ignores the entertainment quality for the children. Disney Company isn't about family values or American ideals but it is about profit or the increasing wealth for Disney shareholders. The stories of Disney films are carefully crafted and told from a Disney-point-of view or Disney Design. Looking at Disney corporate literature may help to put this all into perspective: if the golden rule we learn in Aladdin that is the one who owns the gold makes the rules, it applies in the real world. We can see that Disney owns the gold and makes the rules. Its corporate literature reinforces the power the company has by pointing out its position as the world's largest entertainment company, in addition to the foundation of "Disney name." Both of these factors are necessary for efforts to increase wealth for Disney

REGISTER, VOL. 1, N0. 1, 2008 
shareholders. The Disney Company has something in common with John Smith statement in Pocahontas film: it is still seeking land to claim and to tame. It plans to expand into worldwide markets. Disney doesn't follow the rules but it sets out for world entertainment. It makes its own rules and maintains its power and privilege as producers of cultural texts that serve to rein scribe the ideologies creating dominant and subordinate peoples.

\section{Conclusion}

The Walt Disney Company is a symbol of culture. It has produced films that have been translated into many languages around the world, and has exposed these audiences around the world to various cultures. This company was not only able to produce such a well known entertainment for children but also for adults through the contents and the construction of his films.

There are some characteristics of Disney's animated films such as, its production is a kind of an everlasting product since it uses mostly folk narratives particularly fairytales as the basic story, its films always use the most sophisticated technology and technique, and it has great power to

communicate through its characters. Almost all Disney films are not only intended to be the entertainment for American people but also people all over the world.

Most of folk narratives which were used in Disney films were adapted from other countries' stories. However, Disney intentionally adapts foreign countries' stories in its animated films without finding similarities between alien cultures and its own Disney's rules. In the process of bridging the gap between civilizations, it finds more stability in familiarity and demonstrates Disney ideas to dominate its films. It is common for the audiences to find

REGISTER, VOL. 1, N0. 1, 2008 
Disney's Americanization in almost all its films such as the concept of feminism, discrimination, racism, or rebelliousness in Disney's adaptation films. It also frames and shapes the values of other countries' stories in certain formula that must be well liked by the consumers to blow up the sale of the films. Disney rules that there is only one romantic love for every protagonist that is waited to be found, good looking is everything, power is more appealing, every character needs a magic or a wish to get his dream, it is fine to laugh at developmentally disabled characters, it tends to ignore people of color, there is a culture distortion in some its stories, happiness and fulfillment in its films are linked to buying other Disney products. The adaptation of some stories from other countries is not meant to glorify the uniqueness of other countries' culture but to find out the products which are easy to be made in the form of toys.

As one of the most powerful media conglomerates in the world, Disney works endlessly to set out world entertainment. Although there are so many criticisms toward its films, this company will still make its own rules to use Disney formula and maintain its power as producers of cultural texts. In its search for new markets and greater profits, Disney consistently and creatively finds ways of presenting its films, as objects of consumption rather than objects of children education. Art in the Magic Kingdom becomes a display intended to create new markets, stimulate children to buy all its products, and provide vehicles for merchandizing its endless collection of toys, gadgets, clothes, home accessories and other commodities. Disney has an excellent ability to use films and other forms of children's entertainment as launching pads for a huge collection of toys in which it can cooperate with other huge companies to sell its products. That is the most rational reason why Disney must be able to create such a fascinating or exciting film

REGISTER, VOL. 1, N0. 1, 2008 
especially for the children since it will influence its other products in Disney Store, Disney Channel, Disney magazine, Disneyland, and Disney World.

9Disney's pre-condition to reach top of films showing have been started by introducing the original soundtrack of those films. It carries the popular singers' names such as Phil Collins, Peabo Bryson, Celine Dion, Regina Belle, Elton John, Ricky Martin, Boyzone, and so on. Disney has always been serious to think about the way of their films precondition. It is clear that various sectors were done to get one and the same aim, maximization of profit. In the audiences' point of view, they also get some advantage such as they feel comfortable and satisfied in watching each Disney's film because of the using of high technology and the newest technique in Disney's film.

The entire data above have meaning for cultural industrial growth in Indonesia because global capitalism growth also induces our country. The first, Indonesian animators or film script writers can imitate Disney's ways in integrating all media power that they own for the sake of their sale. The producer of Si Unyil can learn Disney's ways in increasing the sale in domestic consumers specifically. Although we know clearly that industry of our media is still left behind and has not been ready to compete with American animation, we must start to learn to use sophisticated technology to make Indonesian animation better so that our local figures such as Gatutkaca, Arjuna, Si Unyil, Kabayan, Si Entong will be more popular than Tarzan, Mickey Mouse or Winnie the Pooh. Secondly, Disney Corporation has the power to reproduce and transmit Disney formula that maintain and sustain its power and authority as producers of cultural texts. It has the ability to be involved in almost any type of media market that it desires. This allows them to make money in a wide variety of ways since Disney has made great efforts to expand its audience to the international community. The "Disneyzation" is

REGISTER, VOL. 1, N0. 1, 2008 
also included in the way to make money. As the consumers of its films, the people sometimes do not realize the Disney's messages such as Americanization and consumerism which are sent through its films whereas the audiences are world wide. So, parents or teachers must be responsive of this and eager to discuss about the film content, meaning, and message in Disney films or other popular culture products with their children to filter the suitable values for Indonesian children.

\section{References}

Addison, E. 1993. Saving Other Women from Other Men: Disney's Aladdin. Journal of Popular Culture, 20 (2)

Bell, Elizabeth, Lynda Haas, and Laura Sells. 1995. From Mouse to Mermaid: The Politics of Film, Gender, and Culture. Indiana University Press, Indianapolis.

Berland, D. I. 1982. Disney and Freud: Walt meets the idol. Journal of Popular Culture. 23(3).

Brockway, R.W. 1989. The masks of Mickey Mouse: Symbol of a generation. Journal of Popular Culture, 22 (4), 25.

Bryman. A, 2000. Disney and his Worlds. Routledge, London.

Chang \& Ha-Joon. 2003. Globalization, Economic Development, and the Role of the State.New York: Zed Books,

Chesebro, J. W., \& Bertleson, D.A. 1996. Analyzing Media: Communication Technologies as Symbolic and Cognitive Systems. New York: Guilford Press.

Christensen, Chelsea. 2004.The Disney Freak Website. 25 (11). Retrieved fromhttp://www.angelfire.com/movies/disneybroadway

Croce, P. J. 1993. A Clean And Separate Space: Walt Disney In Person And Production. Journal of Popular Culture, 23 (3)

Edgerton, G., \& Jackson, K.M. 1996. Redesigning Pocahontas: Disney, The "White Man's Indian," And The Marketing Of Dreams. Journal of Popular Film and Television, 24 (2)

REGISTER, VOL. 1, N0. 1, 2008 
Fiswick, Marshall. 1974. Parameters of Popular Culture.Bowling Green University Popular Press, Ohio.

Fox, J. 1993. Aladdin Becomes a \$200-Million Genie for Disney. The Los Angeles Times, 21 (4)

Frankel. Han, H. 1976. The Flowering Plum and the Palace Lady: Interpretations of Chinese Poetry.New York: Yale University Press.Retrieved fromhttp://www.chinapage.com. Mulan-e html.

Giroux, Henry A. 1999. The Mouse That Roared Disney and the End of Innocence. Rowman \& Littlefield Publishers, Inc., Maryland.

Goldin, Claudia. 1999. Understanding the Gender Gap: An Economic History of American Women.New York: Oxford University Press.

Hansen, M. 1993. Of Mice and Ducks: Benjamin and Adorno on Disney. South Atlantic Quarterly.

Hiassen, C. 1998. Team Rodent: How Disney devours the world. NY: Ballantine.

Hoerner, K. L. 1996. Gender Roles in Disney films: Analyzing behaviors from Snow White to Simba. Women's Studies in Communication

Jackson, K. M. 1990. Walt Disney: A bio-bibliography. Greenwood: Westport.

Kanfer, S. 1997. Serious business: The Art and Commerce of Animation in America from Betty Boop to Toy Story. New York: Scribner.

Kilpatrick \& Jacquelyn. 1995. Disney's 'Politically Correct' Pocahontas: Race in Contemporary American Cinema: Part 5. ProQuest. Washington State University Library. Article 9186239. Retrieved at 26 February 2007 from http://ntserver1.wsulibs.wsu.edu

Kuenz, J., Klugman, K., Waldrep, S., \& Willis, S. 1995. Inside the Mouse: Work and play at Disney World. Durham: Duke University Press.

Kunzle, D. Introduction. 1990. In A. Dorfman \& A. Mattelart (Eds.). How to read Donald Duck: Imperialist Ideology in the Disney Comic. New York: International General.

Lawrence, E. A. 1986. In the Mick of time: Reflections on Disney's ageless mouse. Journal of Popular Culture, 20 (2)

Lyn, Spillman. 2001. Introduction: Culture and Cultural Sociology. Blackwell Publishers Inc., Massachusetts.

REGISTER, VOL. 1, N0. 1, 2008 
Maio.K. 1999. Woman, Race, and Culture in Disney's Movies. Retrieved at 20 March 2007 from http://www.gol.com/users/bobkeim/Disney/Diswomen.html

Maltin, L. 1986. Of mice and magic: A history of American Animated Cartoons. In Journal of Popular Culture, 20 (2)

Marylynn. Salmon. 1996. Women and the Law of Property in Early America.Chapel Hill: University of North Carolina Press.

McDowell,T. 1948. American Studies. Minneapolis: The University of Minnesota Press 1948.

Moellenhoff, F. 1989. Remarks on the popularity of Mickey Mouse. Journal of Popular Culture, 22 (4)

Nguyen, Mimi.2001. Negotiating Asian American Superpower in Disney's Mulan.Retrieved atJanuary 2007. 8. from PopPolitics.com. http://www.poppolitics.com/articles/2001-01-05-mulan.shtml

Ostman, R.E. 1996. Disney and its Conservative Critics: Images versus Realities. Journal of Popular Film and Television

Eneste, Pamusuk. 1991. Novel dan Film. Penerbit Nusa Indah, Jakarta.

Real, M. 1977. Mass Mediated Culture. New York: Englewood Cliffs.

Sapiro, Virginia. 1986. Women in American Society: An Introduction to Women's Studies. California: Mayfield Publishing Company.

Schickel, R. 1998. The Disney Version: The life, times, art, and commerce of Walt Disney. New York: Simon \& Schuster.

Schweizer, Peter, and Rochelle Schweizer. 1998. Disney: The Mouse Betrayed: Greed, Corruption, and Children Risk. Washington D.C: Regenery Publishing Inc.

Smoodin, E. (Ed.). 1994. Disney discourse: Producing the Magic Kingdom. New York: Routledge.

Solomon, Charles. 1994. The History of Animation: Enchanted Drawings. USA: Outlet Books Company.

Strinati, Dominic, 2003. An Introduction to Theories of popular Culture (terj. Popular culture: Pengantar Menuju Teori Budaya Populer oleh Abdul Mukhid). Yogyakarta: Bentang. London: Routledge.

REGISTER, VOL. 1, N0. 1, 2008 
Tavin, Kevin M., and David Anderson. 2003. Teaching Visual Culture: Deconstructing Disney in the Elementary Art Classroom. Art Education Journal. ProQuest Washington State University Library. Article 334731281. Retrieved at 25 January 2007 fromhttp://ntserver1.wsulibs.wsu.edu.

Tate, Cecil F. 1973. The Search for a Method in American Studies. USA: University of Minnesota press.

Thomas, B., \& Johnston, O. 1984. Disney animation: The Illusion of life. New York: Abbeville Press.

Thomas, B. 1998. Building A Company: Roy O. Disney And The Creation of An Entertainment Empire. New York: Hyperion.

Tong, Rosemarie Putnam.1998. Feminist Thought: Pengantar Paling Komprehensif kepada Arus Utama pemikiran feminis. Yogyakarta: Jalasutra.

Usman, Sunyoto. 2004. Sosiologi: Sejarah, Teori dan Metodologi. Yogyakarta: CIReD

Van Evra, J. 1990. Television and child development. New York: Hillsdale.

Virginia Saphiro. 1986. Women in American Society: An Introduction to Women's Studies. California: Mayfield Publishing Company.

Waller, James. 1998. Face to Face: The Changing State of Racism across America. New York: Current Publisher.

Ward, A.R. 1993. The Lion King's Mythic Narrative. Journal of Popular Film and Television

Wasko, J. 2001. Understanding Disney: The Manufacture of Fantasy.Cambridge: Polity Press.

Wasko, J. Phillips,M. and Meehan,E. 2001. Dazzled by Disney? The Global Disney Audiences Project.London: Leincester University Press

Waters, M.1995. Globalization . New York: Routledge.

Whittock, T.1990. Metaphor and Film. Cambridge University Press, New York.

Wilson, A. 1999. Technological Utopias. South Atlantic Quarterly

Wilson, Stan.L.R. 1995. Mass Media/Mass Culture: An Introduction. USA: Mc Graw-Hill Inc.

http: //en.wikipedia.org/wiki/Aladdin_(1992_Film)

REGISTER, VOL. 1, N0. 1, 2008 
http://en.wikipedia.org/wiki/Mulan_Film.

http://en.wikipedia.org/wiki/Beauty_and_the_Beast_1991_film.

http://en.wikipedia.org/wiki/The_Hunchback_of_Notre_Dame_(1996_film)

http://en.wikipedia.org/wiki/Pocahontas_Film

http://en.wikipedia.org/wiki/Lion_King_film.

http://en.wikipedia.org/wiki/Snow_White_Film

http://en.wikipedia.org/wiki/Cinderella_Film

http://en.wikipedia.org/wiki/Little_Mermaid

http://en.wikipedia.org/wiki/Snow_White.

http: //en.wikipedia.org/wiki/fairytales.

http://en.wikiquote.org/wiki/Animation

http://en.wikipedia.org/wiki/Disney_Animation.

http://en.wikipedia.org/wiki/Capitalism.

http://www.pitt.edu./ dash/beauty.html\# Beaumont

http://en.wikipedia.org/wiki/Stereotypes_of_Arabs_and_Muslims

http://en.wikipedia.org/wiki/Hua_Mulan

http://www.case.edu/alfil/sce/Texts_2001/Needham

http://www.globalenvision.org/index.php.

REGISTER, VOL. 1, N0. 1, 2008 